\title{
Induction of the phage resistance in the progeny of an infected bacterial cell
}

\author{
Tamara P. Pererva
}

Irsitute of Molecular Biology and Genetics, National Academy of Sciences of Ukraine !50. Zabolotnoho str., Kyiv, 252627, Ukraine

Using bacteriophages MS2, PI7 and $\lambda$-vir infecting Escherichia coli AB 259 (Hfr 3000), E. coli MIT and $E$. coli C600 cells appropriately the author demonstrates that both RNA- and DNA-containing phages induce the development of phage-resistant forms appearing with high frequency in the progeny of infected cells.

The problem of viruses interaction with their host cells keeps always its actuality because it includes such crucial problems as the development of lytic and persistent infections as well as the establishment of lysogeny in bacteriophages or of the analogous process of the viral genome integration into the eucaryctic host chromosome. The principal mechanisms of these processes and their consequences both for viruses and virus-infected cells are well studied and keep to be studied in a lot of systems. However, I would like to emphasize there are some phenomena in this ficld being almost absent or beyond priority research studies; these phenomena which might have been of the greatest value, both in theory and practice, include the development of resistant cells in the progeny of sensitive ones having survived the virus infection. In fact, this direction of scientific investigations confirmed mostly at the level of Iysogenic conversion in bacteria and of neoplastic transformation of eucaryotic cells was almost crossed out because of the attractive and convicting theory postulating the selection of spontaneous mutant forms [1]. Nobody has taken into consideration a possibility that some other parallel processes taking place in the infected cells in the course of the phage infection may accompany the incontestable process of the mutant forms selection. So during persistent infections or under some conditions favourable for the infectious process delay due to the cultivation parameters or to

(C) T. P. PERERYA, 1999 some mutations of the phage or of the cell genome the infected cell becomes the carrier of the replicating phage nucleic acid; such a situation being the best one for phage and cell genomes interactions at the level of their recombination. The conditions of the quick $1 y$ tic infection promote, first of all, the spontaneous mutants selection while the delayed phage infection process may be thought to further the development of phage-induced mutations as a result of intimate phage and cell chromosomes interactions.

At one time we elaborated successfully a sinuple approach permitting to achieve some conditions favourable for such interactions and for distinct separation of these two processes - - spontaneous phage-resistant mutants selection and induction of such forms in the course of the phage infection. In the first case the research is made at the level of cell populations in the second one it is reduced to the analysis of the progeny of the phage -infected susceptible cell, i. te. to the investigation of a single cell formed colony.

Our first experiments concerning the induction of the phage resistance in Escherichia coli Hfr 3000 made using the phage MS2 [2] were preceded by our observation of this phage infected population accumulating very quickly the phage resistant forms. To determine whether such phage resistance is due to the preexistence of some resistant cells or it might have been interpreted as a result of some phage-induced changes, we elaborated our own approach to investigate the progeny of a wittingly susceptible cell having survived the phage infection. Such an approach gives us the right to exclude the problem of the 
primary resistant cells selection, such a possibility being already proved without any doubt. Instead of it we examine a situation where the population studied has been originated from a single susceptible phageinfected cell and plated on the solid medium to obtain separate bacterial colonies. Such infected cells, contrary to non-infected and resistant ones, form on the solid medium their characteristic colonics having a dense center and transparent wavy edges (see Fig. 1). Having sown the material from such colonies we detect they to contain about $(1-2) \cdot 10^{9}$ plaqueforming units and about $1 \cdot 10^{8}$ bacteria. The forming of infective centers from the material sown from surh a wavv colony may occur due to the free phage: particles as well as to the cell carrying the phage pregeny and having not been yet lysed. To analyze the progeny of such wavy colony concerning its aquired phage-resistance, the whole colony was at first transferred into the tube containing $10 \mathrm{ml}$ of the liquid medium. We then prepared two subsequent ten-fold dilutions of resuspended cells using the same medium volumes, the anti-phage serum in the concentration ten-fold higher comparing to the working one was added to the last cell dilution. This mixture plated on the agarized nutrient medium formed about 100 colonies on a Petri dish. The anti-phage serum having been present in this mixture neutralized the free phage particles of the colony eliminating in such a way its selective action on the Petri dish. The colnnies formed here were usually smooth ones with rare exceptions, $1-2$ colonies among 500 ones having the remarkable wavy edges. Supposing such colonies to be formed by the susceptible infected cells we did

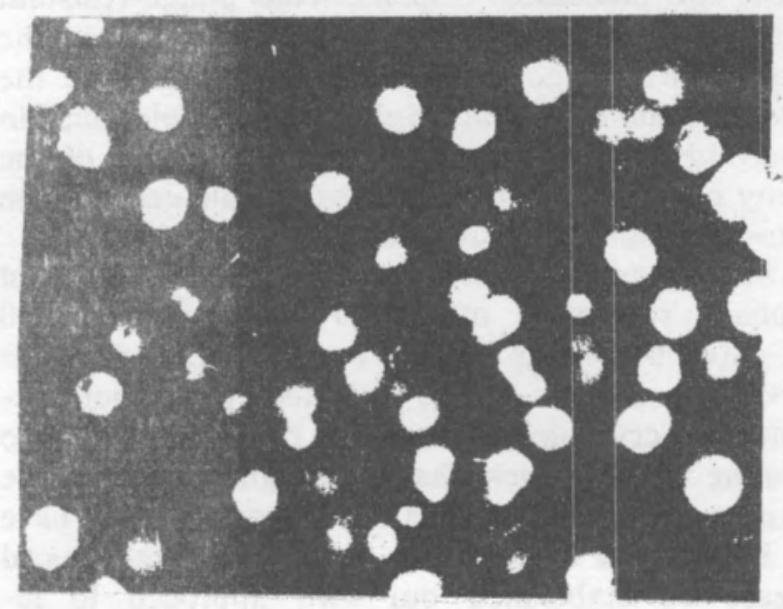

Fig. 1. E. coli AB 259 (Hfr 3000) colonies formed by MS2-infected cèlls not study the phage-resistance but of smooth colonies. Our control colonies were sown from the material of an verified phage-susceptible colony having had no contact with the phage. Our results obtained with the phage MS2 demonstrate about $98.7 \%$ of the infected $E$. coli cell descendants keep their phage susceptibility, the rest of them $(1.3 \%)$, however, aquire the phage-resistance marker. It comprises about $1 \cdot 10^{\mathrm{h}}$ cells per colony; such a quantity of phage-resistant cells might not have developed due to spontaneous mutations and lysed cells death.

The spontaneous development of the phage-resistant cell forms in the case of donor-specific phages may be caused by three types of events such as the sex factor loss by the cell, the $F^{\prime}$-phenocopies accumulation, and the appearance of the sex factor spontaneous mutations. The first event is a very rare one for all the Hfr colls $[3,4]$ with the only exception of especially unstable clones; so we reserve the right to discuss our results without taking such a possibility into consideration. The absence of cell susceptibility to any donor-specific phage may be also dus to the temporary cell state, the cell becoming an $\mathrm{F}^{-}$phenocopy possessing the recepient behavior [5]. However, having, used the spot-test we obtained the phage contact with the growing cell population; the majority of its cells surpass the stage of F-pili formation assuring in such a way the infective phage cycle. We discuss at last the most popular phage-resistance type developing because of the receptor loss. The $\mathrm{R}$-factor mutations leading to the MS2 resistance have bcen shown to occur with the frequency not higher than $10^{-7}[6]$ even after the nitrosoguanidine treatrient and the sclective medium use for the infected cells growth. Both the $\mathrm{R}$ - and the F-factors are known to code the pili formation belonging to the same type, $i$. e. to contain the ideritical region [7], it is possible to suppose the frequency of the spontaneous $F$-factor mutations influencing the phage-resistance is also not higher than $10^{-7}$ per cell per generation. With such mutations frequency the final quantity of mutants developed will not be higher than 10, the quantity of cells in a colony being about $1 \cdot 10^{8}$. This quantity is immeasurably low comparing to the yield of mulants obtained in our experiment $-1.33 \%$ (i. e. $1 \cdot 10^{\mathrm{h}}$ ) from $1 \cdot 10^{8}$ cells. 1 t is completely clear such a cuantity of mutants might not have been developed due to the spontaneous mutations selection and the infected cells death. The number of the last ones is negligible, not higher than $(1--2) \cdot 10^{6}\left((0.01-0.02) \cdot 10^{3}\right)$ according to the plaque-forming units quantity in an infected wavy colony $\left((1-2) \cdot 10^{9}\right)$ and the average viable particles yield per cell $\left(1 \cdot 10^{3}\right)[8,9]$.

So having used the model of the RNA-contaiting 
MS2 phage we have demonstrated that during the prolonged coexistence of the phage and the infected bacterium the phage resistance marker may be both selected and induced by the phage itself. We first supposed our MS2-resistant $E$. coli strains to possess no F-pili. Such a hypothesis has not been, however, confirmed by electron microscopic investigation. In the photos sex-pili are seen carrying adsorbed phage particles (Fig. 2). This adsorption detected under the electron microscope is perhaps of transient character, the infection being unrealized in this system because of phage RNA being incapable of penetrating the cell. Later we have also proved the mechanism of such induction consists of the direct interaction between the phage RNA and F-factor's DNA coding the adsorption receptors of the donor-specific phages on sensitive cells surface $[10,11]$.

A similar situation may develop not only with the MS2 phage, but also with other ones under the analogous living conditions in the course of infection. In our experiments with the phage P17 persistently infecting $E$. coli $\mathrm{M} 17$ and with the phage $\lambda$-vir and its hest, E. coli $\mathrm{C} 600$ we have used the same approach the forming of so-called infective center from a single phage-infected susceptible bacterial cell. It was not difficult with the first system mentioned here, the infected cell plated on the solid medium having formed a rather dense colony of irregular shape (see Fig. 3). While working with the highly virulent phage $\lambda$-vir the infected cell is usually lysed or it forms very minute semi-transparent colonies with the very irregular edges. It is possible to inhibit the lysis of any infected cells on the agarized medium having changed the living conditions of bacteria, such as, for

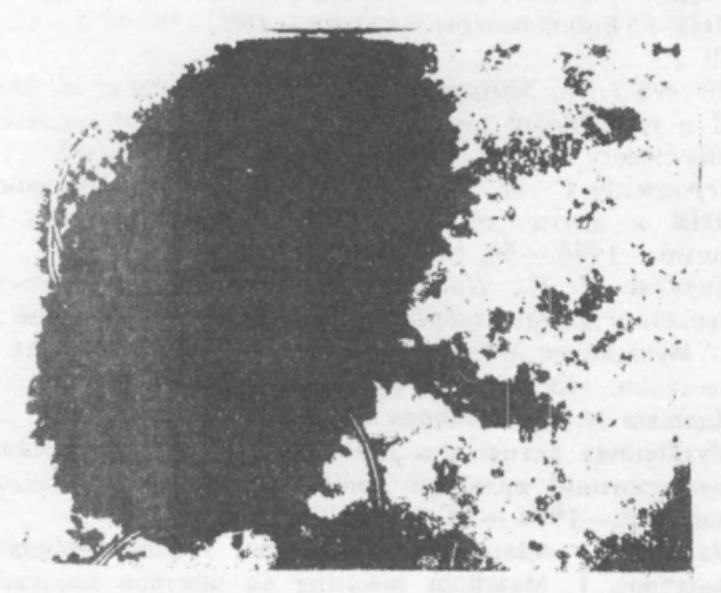

Fig. 2. Electron micrograph of a cell of an MS2 induced phage resistant $E$. coli strain with phage particles adsorbed on F-pili

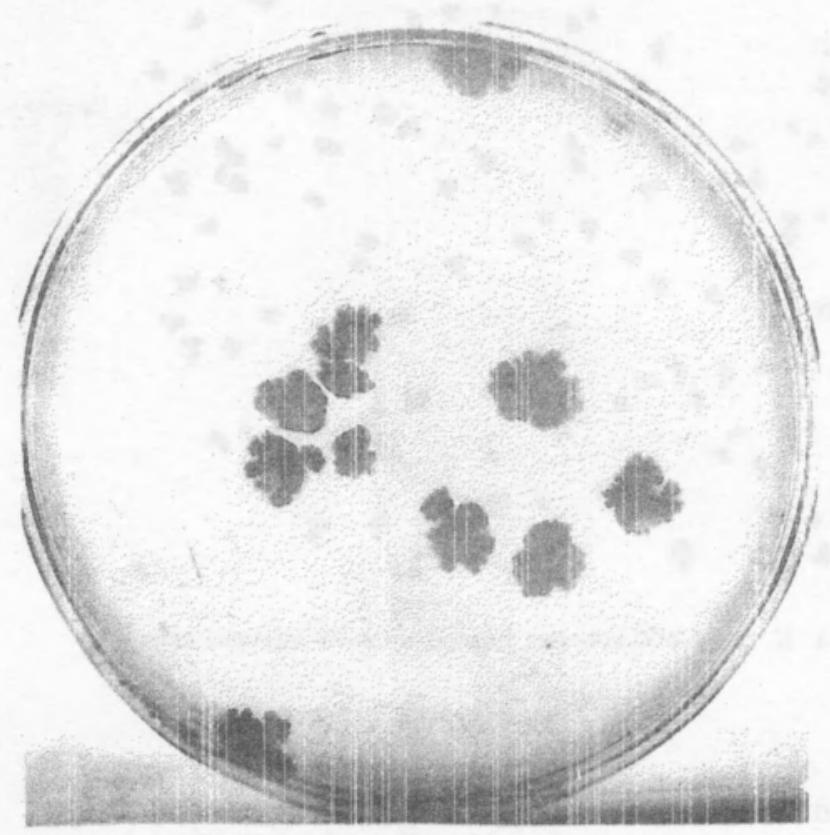

Fig. 3. E. coli M17 colonies formed by P17-infected cells

instance, the temperature of the cultivation. Tho $E$. coli C600 colonies developed from the $\lambda$-vir infected cells are shown in the Fig. 4.

According to our results obtained in these experiments, the replication of the DNA-containing phages under the inhibited growth conditions leacls to the development of resistant forms, their yield being some more higher - about $16-20 \%$. The bacterial mutants appeared in such case keep firmly the aquired phage-resistance marker without ary free phage production, so their development is not accompanied with the formation of any persistent cell system. The most probable interpretation is that in this system, similar to the system formed by the MS2 phage the phage-resistance development takes place at the level of the phage nucleic acid and the cellular DNA interactions; however, due to the participation of the DNA-containing sequences in this process, the genetic recombination may be the simplest result of such interaction. The DNA mutagenic has been proved in a lot of experiments $[12-14]$, so the results obtained with the bacteriophages tested may be interpreted taking into account also this point of view. The investigation of this problem on the level of a single sensitive cell instead of the cell population completes the theory of spontaneous mutations selection by some selective factors; it may be useful for the further study of the adaptive evolution theory, a 


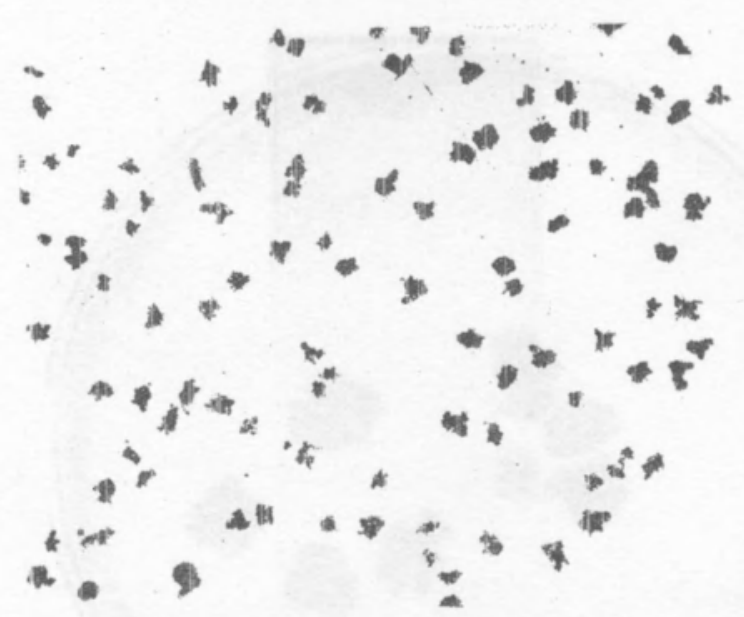

Fig. 4. E. coli C600 colonies formed by $\lambda$-vir-infected cells

scientific field becoming more and more significant and popular during this last decade [15]. The existence of mechanisms assuring the cell infection postulates also the development of some other ones to assure the cell population defense from the infective agent, such a defense being not restricted and due only to the spontancous rnutations selection. Our experimental approach described in this communication permits also to verify the inducible origin of the cellular phage resistance by the investigation of obtained mutants markers using some molecular biological techniques.

The use and development of the approach proposed here is also promising from the biotechnological point of view assuring a completely new protocol permitting to obtain a lot of phage-resistant mutations changing no other cell markers including also the useful ones but the receptor markers only. The phagolysis problem is known to present one time and inother many serious biotechnological complications, the development of the approach to solve this imporant problem being of the greal scientific and practical value.

Acknowledgement. The author thanks Dr Ella Zherebtsova having obtained the anti-phage serum and helped to prepare this manuscript.

\section{11. Hepepsa}

Андукция фагуустойчнвости в нотомстье инфицированной Біктериальной клетки

P'eзiоме

$\because$ использованием бактериорагоя MS2, PI7 и $\lambda$-vir, инфищиру Husic Escherichia coli $A B 259$ (Hfr 3000 ), E. coli M17 u E. coli 1 600 соотзетспьенно, показино, чmо в услоаиях замедленного развития инфекции как РНК-, так и ДНК-содержамие бакте риофаги индуцируют появление высокого процента фасорезистентных форм в клеточном потомстве.

\section{T. 11. Hерерва}

Індукція фагостійкості у потомсгві інфікованої бактеріальної клітини

Резюме

Hа моделях бактеріофахів MS2, P17 ma $\lambda$-vir, мо інфікуюиь Escherichia coli $A B 259$ ( $H$ fr 3000 ), E. coli MI7 ma E. coli C 600 відповідно, показано, що за умов уповільненого розвитку інфекцї як РНК-, так і ДНК-вмісні бактеріофаги спричиняють появу високого відсотка фасостійких форм у клітинному nотомствi.

\section{REFERENCES}

1. Iederberg $J$., Lederberg $E$. $M$. Replica plating and indirest selection of bacterial mutations // J. Bacteriol. $-1952 .-6.3$. N 3.-P. 399-406.

2. Перерва T. ПT. Устойчивость к фагу MS2, индуцированная у $E$. coli при заражении этим фагом // ІІитология и генетика.-1977.-11, № 1.-С. 3-9.

3. Жакоб Ф., Вольман 3. ПІол и генетика у бактерий.-М Изд-во иностр. лит-ры, $1962 \ldots 475 \mathrm{c}$.

4. Hirota $Y u$. The effect of acridine dyes on mating type factors in $E$. coli // Proc. Nat. Acad. Sci. USA. - 1960.-46, N 1 P. $431-435$.

5. Lederberg J., Cavalli $L$. L., Lederberg $E$. $M$. Sex compatibility in E. coli // Genetics. - 1952.-37, N 4.-P. 720-730

6. Orosz $L$ Phage-resistant $R$-factor with geretic transfer ability // Acta microbiol. Acad. sci. hung. - 1972.-22, N 3.-P. 359.

7. Lawn M., Meynell F., Meynell $G$. G., Datta $N$. Sex-pili and the classification of $\operatorname{sex}$ factors in the Enterobacteriaceat // Nature.--1967.-216, N 5113.-P. 343-346.

8. Rappaport 1. Some studies of the infectious process with MS2 bacteriophage // Biochim. et biophys. acta.-1965...B B 03 N 3.-P. 486-499.

9. Strauss J. H., Sinsheimer $R$. L Purification and prop:rties of bacteriophage MS2 and of its ribonucleic acid $/ ! \mathrm{J}$. Mc: Biol.-1963.-7, N 1.-P. 43-54.

10. Перераа Т. ПI., Мирюта 11. Ю., Мирюта А. Ю. ЈІизогения у фага MS2. Синтез фагоспецифичной PIK на клеточной ДНК // Бионолимеры и клетка.-1993.-9, ㅊ. 1.--С. 45 50.

11. Pererva T. P., Miriuta N. Yu., Miriuta $A$. Yu et al. Analysis of a recombinant plasmid containing MS2-like sequence // Biopolimery i kletka.-1995.-11, № 1-C. $61--85$

12. Гериензон С. М. Избирательность мутагенного дейстнин ДНК и других полинуклеотидов // Жури. общ. био логии - 1996. - 56, № 6.-С. $661-682$

13. Карпова И. С., Пидпала О. В. Генетияеская нес:аб. льность у Bacillus subtilis, индуцируемая чужерсдной Цін // Мутагенное действие природных и синтетических нук леотидов.-Киев: Наук, думка, 1990.-C. $48-71$

14. Карпова И. С., Пидпала О. В., ННульженко В. Н. ал dp Мутагенная активность ДНК рекомбинангых плазмид ।. компетентной кульгуре Bacillus subtilis // Цитология и генетика. - 1994.-28, № 1.-C. 66-73.

15. Hall B. C. Adaptive evolution that requires spontaneous mutations. 1. Mutations involving an insertion sequence // Genetics. - 1988. - 120, N 4.-P. 887-897. 